\title{
Sleeping sites of woolly mouse opossum Micoureus demerarae (Thomas) (Didelphimorphia, Didelphidae) in the Atlantic Forest of south-eastern Brazil
}

\author{
Edsel A. Moraes Junior ${ }^{1,2} \&$ Adriano G. Chiarello ${ }^{1}$ \\ ${ }^{1}$ Conservation, ecology and animal behaviour group, Programa de Mestrado em Zoologia de Vertebrados, Pontifícia \\ Universidade Católica de Minas Gerais. Avenida Dom José Gaspar 500, Prédio 41, Coração Eucarístico, 30535-610 Belo \\ Horizonte, Minas Gerais, Brasil. \\ ${ }^{2}$ Corresponding author. E-mail: edsel@biotropicos.org.br
}

\begin{abstract}
Micoureus demerarae (Thomas, 1905) is a medium-sized marsupial, around $130 \mathrm{~g}$, with a nocturnal habit and insectivorous-omnivorous diet. From August 2001 to July 2002, seven individuals, three males and four females, were monitored with radio-telemetry in Reserva Biológica União, state of Rio de Janeiro, Brazil, aiming to investigate and describe the sleeping sites used by this marsupial. Fifty eight sleeping sites were located, most of which $\mathbf{7 0 , 7 \% )}$ in palm trees Astrocaryum aculeatissimum (Schott) Burret, and the remaining in other tree species $(29,3 \%)$, a significant difference $\left(\chi^{2}\right.$ test; $\left.\mathrm{p}<0.005\right)$. The preference for this palm tree was not different between sexes $\left(\chi^{2}\right.$ test; $\left.p=0.920\right)$. It was possible to locate the exact place where the animal was hiding in 31 sleeping sites (53.4\% of total) in palm trees the animals were always in the junction point of petioles and tree trunks, at an average height of $4.66 \pm 1.36 \mathrm{~m}$, while in the remaining tree species, seven individuals were in liana tangles and two in tree holes, at an average height of $10.67 \pm 2.75 \mathrm{~m}$. This height difference was significant (Mann Whitney test; $\mathrm{p}<0.001$ ). Results indicate that palm trees are important resources for M. demerarae. The observed preference for $A$. aculeatissimum is probably due to higher protection against predators made by the numerous spines of this palm tree species.
\end{abstract}

KEY WORDS. Astrocaryum aculeatissimum, radio-telemetry.

RESUMO. Sítios de dormida da cuíca Micoureus demerarae (Thomas) (Didelphimorphia, Didelphidaa) na Floresta Atlântica do sudeste do Brasil. Micoureus demerarae (Thomas, 1905) é um marsupial de tamanho médio, cerca de $130 \mathrm{~g}$, de hábito noturno e arborícola e dieta insetívora-onívora. No período de agosto de 2001 a julho de 2002, sete indivíduos, três machos e quatro fêmeas, foram acompanhados, através de rádio-telemetria, na Reserva Biológica União, Rio de Janeiro, com o objetivo de investigar e descrever os abrigos utilizados por essa espécie de marsupial. Foram localizados 58 abrigos, a maioria dos quais (70,7\%) em palmeiras Iri Astrocaryum aculeatissimum (Schott) Burret e o restante em outras espécies de árvores $(29,3 \%)$, uma diferença significativa (teste $\chi^{2} ; p<0,005$ ). Esta preferência por palmeiras não foi significativamente diferente entre os sexos (teste $\chi^{2}$; $\mathrm{p}=0,920)$. Em 31 abrigos (53,4\% do total) o local exato onde o animal se encontrava pode ser localizado: nas palmeiras os animais sempre estavam alojados no local de inserção dos pecíolos junto ao tronco e a uma altura média de 4,66 $\pm 1,36 \mathrm{~m}$, enquanto nas demais espécies de árvores, sete animais estavam em emaranhados de cipós e dois em ocos, a uma altura média de 10,67 $\pm 2,75 \mathrm{~m}$. Esta diferença de altura entre abrigos em iris e não iris foi significativa (teste Mann Whitney; $\mathrm{p}<0,001$ ). Os resultados indicam que as palmeiras iris são um importante recurso para $M$. demerarae. A preferência por $A$. aculeatissimum se deve provavelmente à maior proteção contra predadores exercida pelos numerosos espinhos presentes nesta espécie.

PALAVRAS CHAVE. Abrigo, Astrocaryum aculeatissimum, rádio-telemetria.

The sleeping or resting site is defined as whatever location the animal spends the night (or day) in a physiological state of rest (DAY \& ElWood 1999). These locations are selected to offer protection against the elements (Aquino \& ENCARNACIÓN 1986) and predators (HamiLton 1982). Locating the sleeping places and refuges of small mammals in an area of forest, using only active searching, is almost impossible. The methods which obtain the best results are 'spool-and-line' (Miles et al. 1981, Wooley 1989, BRIANi et al. 2001) and radio-telemetry (STALLINGS et al. 1994, Sunquist et al. 1987). Miles et al. (1981), using the 
'spool-and-line' method successfully located various nests of different mammal species in four study areas in Brazil. In the radio-telemetry research conducted by STALLINGs et al. (1994) with Kannabateomys amblyonyx (Wagner, 1845) in an Atlantic Forest area, the authors located various refuges of this species.

Micoureus demerarae occurs in South America, from northern Colombia to northern Argentina (EMmons \& FeER 1997). This marsupial has nocturnal habits and can weigh more than $130 \mathrm{~g}$. Micoureus demerarae is characterized by high mobility, with a predominantly tree-dwelling habit (Charles-DominiQue et al. 1981, Miles et al. 1981, Stallings 1988, Fonseca \& KierulfF 1989, Passamani 1995, Pires \& Fernandez 1999) and an insectivorousomnivorous diet (Leite et al. 1994; Carvalho et al. 1999). There is no published information focusing on resting sites of $M$. demerarae. The aim of the present study is, therefore, to describe the types and respective frequencies of the resting sites used by this species, contributing for a better understanding of its natural history.

\section{MATERIAL AND METHODS}

The study was carried out in União Biological Reserve (UBR), a 2,400 ha federal reserve administered by the Brazilian Environmental Agency (IBAMA) and located on the borders of Casimiro de Abreu and Rio das Ostras municipalities, in north Rio de Janeiro state, south-eastern Brazil (22 $27^{\prime} 36^{\prime \prime} \mathrm{S}$, $42^{\circ} 02^{\prime} 15^{\prime \prime} \mathrm{W}$ ). The main vegetation type is dense ombrophilous forest (IвGE 1993). During the study period, annual rainfall was $1,138 \mathrm{~mm}$, with temperatures averaging $24.5^{\circ} \mathrm{C}$. The dry season occurs from April to September, and the wet season from October to March (LAPENTA et al. 2003).

The work was carried out during the study of Moraes JR. \& Chiarello (2005). Traps baited with pieces of banana and cotton soaked in cod liver oil (Scott Emulsion) were used to capture the animals. The traps were located in the sub-canopy (1 to $2 \mathrm{~m}$ high) and on platforms on tree-tops, following Stallings (1988) and Malcolm (1991), with a total capture effort of 1,440 traps-nights. The traps were closed during the radio-telemetry monitoring time to avoid disturbing movements of the animals.

The captured animals were given radio collars manufactured by Wildlife Materials Inc. model SOM-2190. Each individual was followed using radio telemetry for four nights (1800$0600 \mathrm{~h}$ ) each month. A "Telonics" receptor, model TR-2 (frequency 164-165 MHz), a three-element "Yagi" antenna, and ear-phones were used. The sleeping sites were located using triangulation and progressive approximation to the source of signals ("homing-in"; KenWARD 2001). When sleeping sites were encountered, the geographic coordinates, the type of sleeping site (tangles of lianas, hollows in trees, etc) and its height above the ground were recorded. When possible, the exact location of the animal within the sleeping sites was determined and recorded.

\section{RESULTS AND DISCUSSION}

Fifty eight sleeping sites of seven radio-collared individuals were found. The number of sleeping sites located varied among animals. This variation occurred because one animal probably managed to remove its radio collar (individual MD$4 \mathrm{~F}$ ), two individuals were predated (individuals MD-OM and MD-2F) and three radio collars did not work perfectly. The individual with the largest number of located sleeping sites was MD-1F, who was monitored for the longest period (four months) (Tab. I).

Table I. Number and type of sleeping sites used by each individual in the União Biological Reserve, Rio de Janeiro.

\begin{tabular}{cccc}
\hline Individuals & $\begin{array}{c}\text { Sleeping sites } \\
\text { in palm trees }\end{array}$ & $\begin{array}{c}\text { Sleeping sites } \\
\text { in other trees }\end{array}$ & Total \\
\hline MD-0M & 1 & 3 & 4 \\
MD-3M & 6 & 3 & 9 \\
MD-5M & 10 & 2 & 12 \\
\hline Total males & $17(68.0 \%)$ & $8(32.0 \%)$ & 25 \\
\hline MD-1F & 15 & 2 & 17 \\
MD-2F & 1 & 2 & 3 \\
MD-4F & 3 & 2 & 5 \\
MD-6F & 5 & 3 & 8 \\
\hline Total females & $24(72.7 \%)$ & $9(27.3 \%)$ & 33 \\
Total & $41(70.7 \%)$ & $17(29.3 \%)$ & 58 \\
\hline
\end{tabular}

From the total of 58 sleeping sites, $70.7 \%(n=41)$ were located in palms known locally as 'iri' or 'brejaúba', Astrocaryum aculeatissimum (Schott) Burret (Fig. 1), while the remaining 29.3\% ( $\mathrm{n}=17$ ) were found in non-palm trees (of several species), a significant difference $\left(\chi^{2}\right.$ with Yates correction $=9.121 ; \mathrm{df}=1 ; \mathrm{p}$ $<0.005)$. None were found on the ground. Of the 25 sleeping sites used by males, $68 \%$ were in palms and $32 \%$ in other tree species. Of the 33 sleeping sites used by females, $72.7 \%$ were in palms and $27.3 \%$ in other trees (Tab. I). These differences between males and females were not significant $\left(\chi^{2}\right.$ with Yates correction $=0.010 ; \mathrm{df}=1 ; \mathrm{p}=0.920$ ). Micoureus demerarae used palm trees with higher frequency than non-palm trees as resting sites $\left(\chi^{2}\right.$ with Yates correction $\left.=9.121 ; \mathrm{df}=1 ; \mathrm{p}<0.005\right)$, and this preference was held constant between the two seasons $\left(\chi^{2}\right.$ with Yates correction $=1.981 ; \mathrm{df}=1 ; \mathrm{p}=0.159)$ (Tab. II).

In only 31 sleeping sites ( $53.4 \%$ of the total) the exact location of the nest in the tree or tree palm could be determined with certainty. In $100 \%$ of these occasions the animals did not change position within the sleeping sites during the diurnal period. Of these 31 nests, 22 were located in palm trees (iri palms), always in the insertion point of petioles in the tree trunk. This part of the palm tree normally accumulates a great amount of dry leaves of other tree species, forming a sort of 


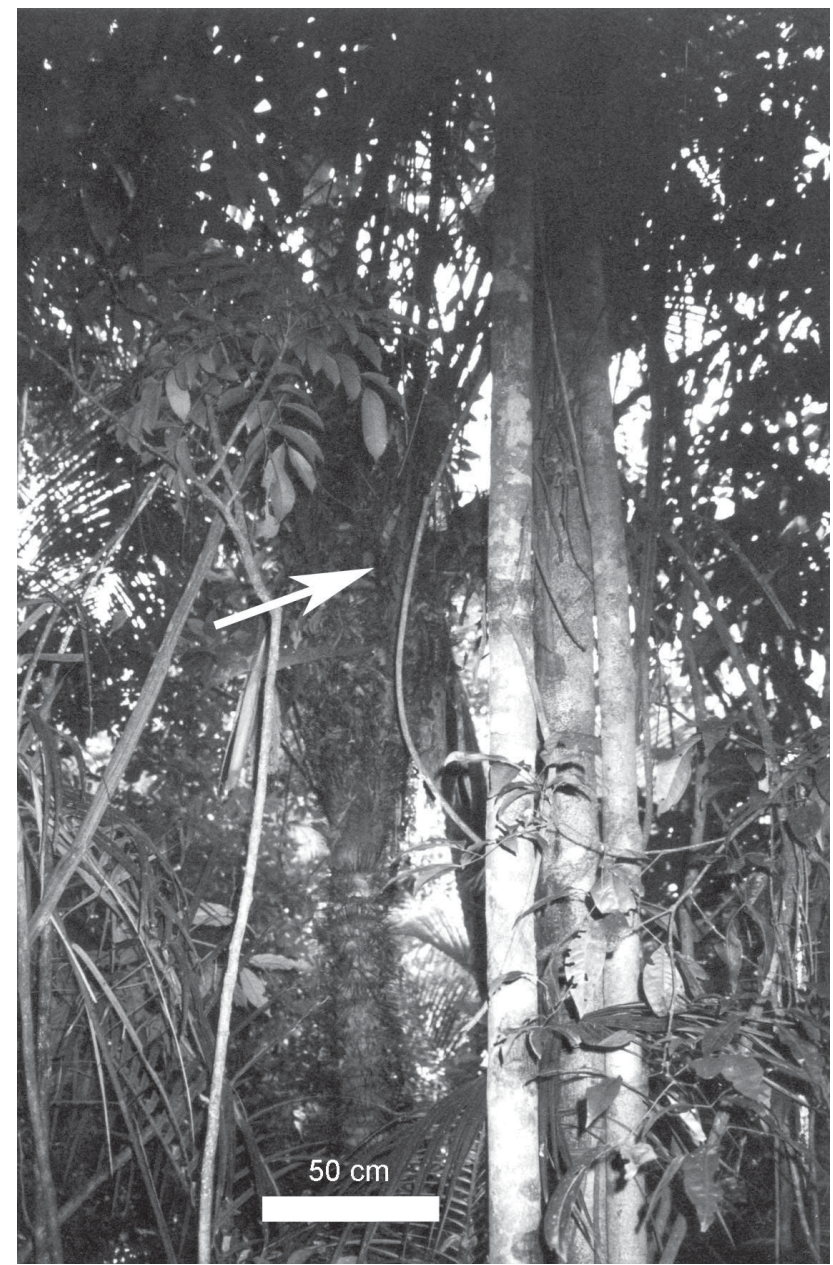

Figure 1. The 'iri' palm (Astrocaryum aculeatissimum) used as a frequent sleeping site by Micoureus demerarae in the União Biological Reserve, Rio de Janeiro. The arrow indicates the exact position of an observed sleeping site.

Table II. Number of sleeping sites observed and expected (in brackets) in the União Biological Reserve, in relation to location (palms and trees) and seasons of the year (dry and wet).

\begin{tabular}{lcc}
\hline \multicolumn{1}{c}{ Local of sleeping site } & Dry season & Wet season \\
\hline Palm trees & $12(14.80)$ & $29(26.2)$ \\
Other trees & $9 \quad(6.16)$ & $8(10.8)$ \\
\hline Total & 21 & 37 \\
\hline
\end{tabular}

natural nest (Fig. 1). The average height of sleeping sites located in palm trees $(n=22$; average $=4.66 \pm 1.36 \mathrm{~m})$ was significantly lower than that of sleeping sites located on non-palm trees $(\mathrm{n}=9 ; 10.67 \pm 2.75 \mathrm{~m})($ Mann-Whitney test; $\mathrm{U}=4.5 ; \mathrm{W}=$ 257.5; $\mathrm{p}<0.001)$.
Several animals used the same sleeping sites more than once. The male MD-5M was the individual who used the same sleeping sites most often, sleeping in the same palm tree five times and in another one four times. The individual with the longest monitoring period (MD-1F) used the same sleeping site three times during the month in which she was recaptured for radio-collar replacement. Handling of this female allowed us to ascertain that she was lactating.

It was reported in a previous paper (MORAES JR. \& CHIARELlo 2005) that sleeping sites of $M$. demerarae are located inside or close to the areas most intensely used by these animals, suggesting that they concentrate their activities close to their sleeping sites. This study is the first record of M. demerarae using o A. aculeatissimum as a sleeping site. Interestingly, the sleeping sites in this palm tree were always located in the insertion point of petioles in the tree trunk. This is a sheltered place, so perhaps it allows better protection against sunlight for the strictly nocturnal M. demerarae (EMMONs \& FeER 1997). More importantly, this palm tree has many spines on its trunk and leaves (Fig. 1) a physical barrier that certainly offer protection against predators. This reasoning is corroborated by the finding that resting places in palm trees were located at significantly lower heights above the ground when compared to nests located in non-palm trees. We also believe, however, that this particular location (the insertion point of petioles) may additionally serve as potential sources of food, as many invertebrates can hide there, as observed by Wooley (1989) in New Guinea.

In the study of Didelphis marsupialis Linnaeus, 1758 by SunQuist et al. (1987), the authors did not find a significant difference between the types of resting places used by males and females, but observed that males change their sleeping sites more frequently than females. They also observed a significant difference in the type of resting site used between seasons for all monitored individuals, unlike the observed in present study. In the wet season, for example, the sleeping sites of $D$. marsupialis were located most frequently on the ground, and in trees during the dry season (Sunquist et al. 1987). As $D$. marsupialis has a scansorial habit (EMmons \& FEer 1997) it can use a larger variety of sleeping sites. On the other hand, no nest was found on the ground in the present study, which indicates the predominantly arboreal habit of $M$. demerarae (Passamani 1995, Pires \& Fernandez 1999).

In the study by Miles et al. (1981) the authors located three sleeping sites of Marmosa cinerea Temminck, 1824 (= Micoureus demerarae), of eight individuals followed using the 'spool and line' technique. The animals were found in tree hollows and palms, always far from the ground, corroborating the results of the present study. However, these authors did not manage to verify the frequency with which the animals used these sleeping places. The repeated use of sleeping sites observed in some animals is important, and could be understood as a strategy to stay close to food sources, better efficiency against predators, territorial defence or care for offspring. 
STALLINGs et al. (1994) observed, for example, that the bamboo rat Kannabateomys amblyonyx used one or two sleeping sites more than $50 \%$ of the time, arguing that this might be related to territorial protection. As the females of $M$. demerarae are territorial (PIres et al. 1999), the location and frequency of use of their sleeping sites could also be important factors in territorial defence against neighbouring females. For males, however, the location of nests could be influenced by the location of food resources in the environment and perhaps by the location of female sleeping sites during the reproductive season.

The fact that M. demerarae makes intensive use of the 'iri' palm (Astrocaryum aculeatissimum), which has a large geographic distribution, from the state of Bahia to Santa Catarina, occurring in evergreen costal forests and in open areas (LoRENzi et al. 1996), suggests that this palm species could be an important resource for $M$. demerarae. Unfortunately we have no information about the density of this palm in the study area. Data from another site located further north (Espirito Santo state) with a similar forest type (lowland moist forest) indicates, however, that A. aculeatissimum occurs at density of 2 individuals/0.1 ha (> 10 $\mathrm{cm}$ at breast height; Peixoto \& Gentry 1990). If extrapolated to a larger sampling plot, this figure would generate an approximate density of 20 palms/ha, that might be considered as intermediate density when compared to other Atlantic forest tree species (Peixoto \& Gentry 1990, SAnchez et al. 1999). Other studies carried out in the Atlantic Forest demonstrate that Arecaceae (= Palmae) is generally among the most important family in terms of number of individuals (SANCHEZ et al. 1999). Moreover, these authors consider A. aculeatissimum as a species of early secondary succession, that is, those species that establish soon after forest disturbance (SANCHEZ et al. 1999). Considering these information we speculate that $M$. demerarae is using an resource that is probably not rare in the forest, particularly those forest fragments highly impacted by edge effects or other anthropogenic disturbances such as fire and selective logging.

We sometimes tend to overestimate the importance of food sources for the survival of individuals in a particular forest site, not considering that other types of resources such as shelters or sleeping sites might be equally important. In this sense, given the intense fragmentation of the Atlantic forest, perhaps the presence $A$. aculeatissimum constitute an important factor for the successful establishment of dispersing individuals into new areas (or fragments), or for maintenance of metapopulations in a matrix of degraded forest fragments (BRITO $\&$ FERNANDEZ 2000). Of course, the factors influencing the choice and use of sleeping sites are complex and varied and therefore a larger number of animals should be monitored in other sites of the Atlantic forest to proper test these hypothesis.

\section{ACKNOWLEDGEMENTS}

We wish to thank the Golden-Lion-Tamarin Association for logistic and financial support. We are also grateful to the biologist Paula Procópio Oliveira and the whole team of the lion-tamarin translocation program (Programa de Translocação do Mico-Leão-Dourado). IDEA WILD donated some of the equipment used, and the Brazilian Program CAPES provided a postgraduate scholarship for one of us (E.A.M.J.). The Brazilian Environmental Agency (IBAMA) provided research licenses, and staff of União Biological Reserve, especially its director Whitson José da Costa Júnior, were very helpful during field work. Juliana Quadros carrefully reviewed the manuscript and provided helpful suggestions. Jennifer Toms kindly reviewed the English.

\section{REFERENCES}

Aquino, R. \& F. EnCARNACIÓN. 1986. Characteristics and use of sleeping sites in Aotus (Cebidae, Primates) in the Amazon lowlands of Peru. American Journal of Primatology, Calgary, 11: 319-331.

Briani, D.C.; E.M. Vieira \& A.M.V. Vieira. 2001. Nests and nesting sites of Brazilian forest rodents (Nectomys squamipes and Oryzomys intermedius) as revealed by a spool-and-line device. Acta Theriologica, Bialowiezo, 46: 331-334.

Brito, D. \& A.S. Fernandez. 2000. Metapopulation viability of the narsupial Micoureus demerarae in small Atlantic forest fragmetns in south-eastern Brazil. Animal Conservation, Cambridge, 3: 201-209.

Carvalho, F.M.V.; P.S. Pinheiro; F.A.S. Fernandez \& J. Nessiman. 1999. Diet of small mammals in Atlantic Forest fragments in southern Brazil. Revista Brasileira de Zoociências, Juiz de Fora, 1: 91-101.

Charles-Dominique, P.; M. Atramentowicz; M. Charles-Dominique; H. Gerárd; A. Hladick; C.M. Hladik, \& M. Prevóst. 1981. Les mammiferes frugivores arborícoles nocturnes d'une forest guyanaise: Inter-relations plantes-animaux. Revue d'Ecologie Terre et la Vie, Paris, 35: 341-435.

DAY, R.T. \& R.W. Elwood. 1999. Sleeping site selection by the golden-handed tamarin Saguinus midas midas: The role of predation risk, proximity to feeding sites, and territorial defence. Ethology, Oxford, 105: 1035-1051.

EMmONs, L.H. \& F. FeER. 1997. Neotropical Rainforest Mammals: A field guide. Chicago, The University of Chicago Press, XVI+307p.

FonseCA, G.A.B. \& M.C.M. KierulfF. 1989. Biology and natural history of Brazilian Atlantic Forest small mammals. Bulletin of Florida Museum of Natural History, Gainesville, 34: 99-152.

Hamilton, W.J. 1982. Baboon sleeping site preferences and relationships to primate grouping patterns. American Journal of Primatology, Calgary, 3: 41-53.

IвGE, 1993. Mapa de vegetação do Brasil. Rio de Janeiro, Fundação Instituto Brasileiro de Geografia e Estatística.

Kenward, R.E. 2001. A Manual for Wildlife Radio Tagging. San Diego, Academic Press, 311p.

Lapenta, M.J.; P.P. Oliveira; M.C.M. KierulfF \& J.C. Motta-Junior. 2003. Fruit exploitations by Golden Lion Tamarins (Leontopithecus rosalia) in the União Biological Reserve, Rio das Ostras, RJ - Brazil. Mammalia, Paris, 67: 41-46. 
Leite, Y.L.R.; J.R. Staluings \& L.P. Costa. 1994. Partição de recursos entre espécies simpátricas de marsupiais na Reserva Biológica de Poço das Antas, Rio de Janeiro. Revista Brasileira de Biologia, Rio de Janeiro, 54: 525-536.

Lorenzi, H; H.M. Souza; J.T. Medeiros-Costa; L.S.C.Cerqueira; N. von Berr. 1996. Palmeiras do Brasil: nativas e exóticas. Nova Odessa, Editora Plantarum, 303p.

Malcolm, J.R. 1991. Comparative abundances of Neotropical small mammals by trap height. Journal of Mammalogy, Provo, 72: 188-192.

Miles, M.A.; A.A. Souza \& M.M. PovoA. 1981. Mammal tracking and nest location in Brazilian forests with an improved spool-and-line device. Journal Zoology London, Cambridge, 195: 331-347.

Moraes Jr., E.A. \& A.G. Chiarello. 2005. A radio tracking study of home range and movements of the marsupial Micoureus demerarae Thomas (1905) (Mammalia, Didelphidae) in the Atlantic forest of south-eastern Brazil. Revista Brasileira de Zoologia, Curitiba, 22 (1): 85-91.

Passamani, M. 1995. Vertical stratification of small mammals in Atlantic hill forest. Mammalia, Paris, 59: 276-279.

Peixoto, A.L. \& A. Gentry. 1990. Diversdiade e composição florística da mata de tabuleiro na Reserva Florestal de Linhares
(Espírito Santo, Brasil). Revista Brasileira de Botânica, São Paulo, 13: 19-25.

Pires, A.S. \& F.A.S. Fernandez. 1999. Use of space by the marsupial Micoureus demerarae in small Atlantic Forest fragments in south-eastern Brazil. Journal of Tropical Ecology, Cambridge, 15: 279-290.

Sanchez, M.; F. Pedroni; H.F. Leitão-Filho \& O. Cesar. 1999. Composição florística de um trecho de flroresta ripária na Mata Atlântica em Picinguaba, Ubatuba, SP. Revista Brasileira de Botânica, São Paulo, 22 (1): 31-42.

StAllings, J.R. 1988. Small mammal inventories in an eastern Brazilian park. Bulletin of Florida Museum of Natural History, Gainesville, 34: 153-200.

Stallings, J.R.; M.C.M. KierulfF \& L.F.B.M. Silva. 1994. Use of space, and activity patterns of Brazilian bamboo rats (Kannabateomys amblyonyx) in exotic habitat. Journal of Tropical Ecology, Cambridge, 10: 431-438.

Sunquist, M.E.; S.N. Austad \& F. Sunquist. 1987. Movement patterns and home range in the opossum (Didelphis marsupialis Journal of Mammalogy, Provo, 68: 173-176.

Wooley, P.A. 1989. Nest location by spool-and-line tracking of dasyurid marsupials in New Guinea. Journal Zoology London, Cambridge, 218: 689-700.

Received in 06.XII.2004; accepted in 26.IX.2005. 